\section{[inim] J Oral Res}

\title{
A cross-sectional study on the level of severity of dental caries in adults.
}

\author{
Estudio transversal sobre nivel de severidad de \\ caries dental en adultos.
}

\section{Clarisse Díaz-Reissner. ${ }^{1}$ Juan Roldán-Merino. ${ }^{2-5}$ Irma Casas-García. ${ }^{6-8}$}

Affiliations:

${ }^{1}$ Facultad de Odontología. Universidad Nacional de Asunción. Asunción, Paraguay. ${ }^{2}$ Campus Docent. Sant Joan de DéuFundació Privada. Barcelona, Spain.

${ }^{3}$ Universitat Autònoma de Barcelona. Barcelona, Spain.

${ }^{4}$ Rovira i Virgili University of Tarragon, Tarragona, Spain.

${ }^{5}$ Research Group GEIMAC, Barcelona, Spain.

'Universitat Autònoma de Barcelona. Departamento de Pediatría, Obstetricia y Ginecología y Medicina Preventiva. Barcelona, Spain.

${ }^{7}$ Preventive Medicine Servic. Hospital Germans Trias i Pujol. Barcelona, Spain.

${ }^{8}$ Research Group Innovation in Respiratory Infections and Tuberculosis Diagnosis. Barcelona, Spain.

Corresponding author: Clarisse DíazReissner. Facultad de Odontología. Universidad Nacional de Asunción. Avenida España c/ Brasil No. 430. Asunción, Paraguay. E-mail: cdiazr@odo.una.py

Receipt : : 12/12/2020 Revised: 04/05/2021 Acceptance : 06/30/2021

Cite as: Díaz-Reissner C, Roldán-Merino J \& Casas-García l.

A cross-sectional study on the level of severity of dental caries in adults.

J Oral Res 2021; 10(3):1-10.

Doi:10.17126/joralres.2021.032
Abstract: Introduction: Oral diseases affect some 3.9 billion people worldwide, the most prevalent are dental caries, gingivitis, and periodontitis. Untreated dental caries lesions affect 35\% of the population. Objective: To determine the level of severity of dental caries lesions in adults treated at public dental services in the cities of Asunción and Pirayú, Paraguay, in 2017. Material and Methods: Sociodemographic and clinical variables of oral health status were evaluated by means of a cross-sectional study using consecutive sampling. Two dentists were calibrated to perform the oral examination. Caries experience was evaluated using the DMF-T index. The Chi square test and Fisher's exact test were applied, with a confidence level of $95 \%$. Results: 333 subjects with a mean age of 35 years participated in the study, $77.2 \%$ were females, and $64.0 \%$ did not have access to private health care services. The DMF-T index was 11.43 (SD=6.7); $12.6 \%$ obtained a very low level, $35.7 \%$ low level, $41.7 \%$ had a medium level, and $9.9 \%$ had a high level in the DMF-T index. The DMF-T index was significantly higher in females $(p=0.001)$, in the age range of 50 to 59 years $(p<0.001)$, in those who did not have access to private health services $(p=0.008)$, in those who reported a negative self-evaluation of their oral health $(p=0.04)$, in those with a normal molar ratio $(p=0.023)$ and a very severe aesthetic index $(p<0.001)$. Conclusion: The general level of severity of global caries was medium and associated with sociodemographic and clinical variables.

Keywords: dental caries; DMF index; oral health; cross-sectional studies; diagnosis, oral; Paraguay.

Resumen: Introducción: Las enfermedades orales afectan a 3,9 billones de personas a nivel mundial, siendo las más prevalentes la caries dental, la gingivitis y periodontitis; afectando al 35\% de la población las lesiones de caries dental no tratadas. Objetivo: Determinar el nivel de severidad de lesiones de caries dental en adultos que acuden a servicios odontológicos públicos en las ciudades de Asunción y Pirayú, en el Paraguay, en el año 2017. Material y Métodos: Estudio transversal donde se evaluaron variables sociodemográficas y clínicas del estado de salud oral. El muestreo fue de casos consecutivos. Dos odontólogos fueron calibrados para realizar el examen oral. La experiencia de caries fue evaluada mediante el índice CPO-D. Se aplicaron las pruebas Chi cuadrado y Test exacto de Fisher, con un nivel de confianza 
del 95\%. Resultados: Participaron del estudio 333 sujetos, con edad promedio de 35 años, el 77,2\% mujeres y el 64,0\% no tenía acceso a servicios de salud privado. El índice CPO-D fue de 11,43 $(\mathrm{DE}=6,7)$. El 12,6\% obtuvo un nivel muy bajo, el 35,7\% nivel bajo, el 41,7\% tuvo nivel medio y el 9,9\% nivel alto del CPO-D, siendo significativamente más elevado en mujeres $(p=0,001)$, en la edad de 50 a 59 años $(p<0,001)$, en aquellos que no cuentan con acceso a servicios de salud privado ( $p=0,008)$, los

\section{INTRODUCTION.}

Oral diseases affect 3.9 billion people worldwide, the most prevalent are dental caries, gingivitis, and periodontitis. Untreated dental caries lesions affect $35 \%$ of the population. ${ }^{1}$ This is why caries lesions are considered a public health problem, as they play a key role in the overall health and quality of life of individuals. $^{2}$

Regarding the oral health status of the Paraguayan population, when caries experience was measured in indigenous Paraguayans in the year 1984, a DMF-T of 8.67 was obtained at 20-24 years of age, 9.10 at 2529 years, 8.67 at 30-34 years, 9.64 at $35-40$ years, and 9.84 in those older than 40 years.3 In 12-yearold children from 1994 to 2003, Paraguay obtained an intermediate level of caries. ${ }^{4}$ This level remained fairly stable according to the results of the national oral health surveys carried out in 2008, ${ }^{5} 2014,{ }^{2}$ and 2017.6 In studies conducted in adults over 60 years of age living in nursing homes in the city of San Lorenzo in 2011,7 83.3\% had more than 18 missing teeth, and 33.3\% were totally edentulous. In 2013, a study conducted on those who lived in state-run nursing homes in the metropolitan area of Asunción showed that $44.8 \%$ presented total edentulism. ${ }^{8}$

The Ministry of Public Health and Social Welfare is the governing body of health care provision in Paraguay. ${ }^{9}$ Since 2009, the dental services of the health networks have been strengthened, providing free public care. Additionally, dental specialties were incorporated into the health care network. ${ }^{10}$ Among the strategies implemented for the control of dental caries there are five main programs: "Salvemos al que relataron una autoevaluación negativa de su salud bucal $(p=0,04)$, los que tenían una relación molar normal $(p=0,023)$ e índice de estética muy grave $(p<0,001)$. Conclusión: El nivel general de severidad de caries global fue medio, se asoció con variables sociodemográficas y clínicas.

Palabra Clave: caries dental; índice CPO; salud bucal; estudios transversales; diagnóstico bucal; Paraguay

primer molar", "Volver a sonreir", "Paraguay sonríe", "Mil niños libres de caries" y "Embarazo saludable con boca sana" ("Let's save the first molar", "Let's smile again", "Paraguay smiles", "A thousand children free of cavities", and "Healthy pregnancy with a healthy mouth.") Among the treatments offered are cleft lip and palate surgery, prosthetic rehabilitation, and dental care for people with disabilities. In addition, prevention campaigns were implemented in schools in all the regions of the country. ${ }^{6,11}$

The present study is relevant because there are no reports on the level of severity of dental caries at the national scale, and there are only few published studies on oral health in the Paraguayan adult population. Consequently, the aim of the present study was to determine the level of severity of caries in adults treated at public dental services in 2017.

\section{MATERIALS AND METHODS.}

Adults treated at the following health care centers during the first quarter of 2017 participated in the study: San Vicente de Paul Health Center of the XVIII Sanitary Region, and Pirayú Health Center of the IX Sanitary Region, both managed by the Ministry of Public Health and Social Welfare of Paraguay, the School of Dentistry of Universidad Nacional de Asunción, and the Chacarita Community Center. Paraguayan patients of both sexes with ages ranging from 18 to 59 years and naturalized foreigners with more than fourteen years in the country were included in the study.

The two departments studied are highlighted in dark yellow in the map below (Figure 1). 
To calculate sample size, considering the total number of 542,895 inhabitants in the cities of Asunción and Pirayú, the results of the variance estimate of 49 obtained in the DMF-T of the pilot test were used as a reference. With a precision of the 1\%, and a confidence level of 95\%, it was necessary to recruit a minimum of 188 patients, but considering a $15 \%$ loss of data, 221 patients were finally included in the study.

Sampling consisted of consecutive cases until the required sample size was obtained. Patients invited to participate in the study were asked to sign an informed consent form. They were free to participate or withdraw from the study and continue receiving care in the institution. The sample aims to be representative of the different socioeconomic strata. There is currently no evidence suggesting differences in the DMF-T index in adults, since this is the first study carried out in this age group.

Two dentists were calibrated to perform the oral examination (Cohen's Kappa=0.84). The criteria of the World Health Organization (WHO) for epidemiological studies were followed. ${ }^{12}$

For the calibration process, a written test based on the operational definitions manual was performed

Figure 1. Map of Paraguay. Departments included in the study (Central and Paraguarí).

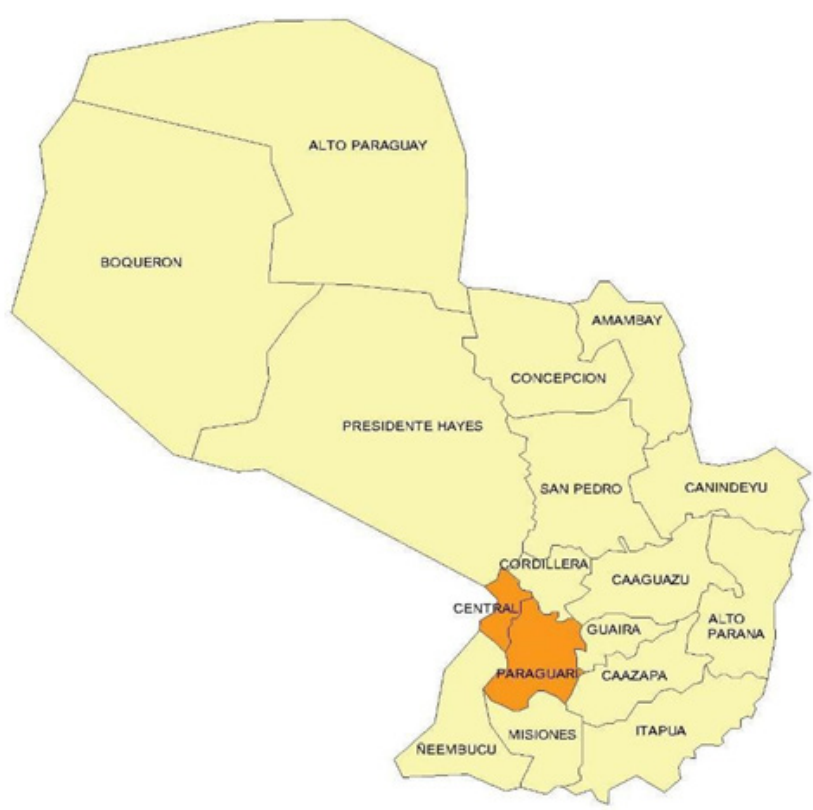

as theoretical training. Afterwards, training and calibration sessions were held, where the agreement was evaluated using photographs. Finally, a calibration process was performed in patients who were not part of the study.

The clinical calibration process was carried out on three occasions, until the result yielded values greater than 0.80 in the Kappa Index in all sections, resulting in a total of 18 patients who were excluded from the study (Table 1). Caries experience was assessed using the DMF-T index, adding the number of decayed, missing and filled teeth. The level of severity of caries in adults was determined according to the following scale: from 1 to 3 it was considered very low, from 4 to 10 as low, from 11 to 20 as medium, and from 21 to 28 as high. ${ }^{13}$

The sociodemographic variables related to the DMF-T index were age, sex, place of residence, educational level, occupation, income level, access to private health services (Table 2). The clinical variables were self-perceived oral health status, signs (clicking, pain on palpation, lesions of the oral mucosa), and symptoms in the temporomandibular joint (TMJ), molar ratio (normal, semi-cusp, cusp), dental aesthetic index (mild, moderate, severe, and very severe

Figure 2. Caries experience by severity level.

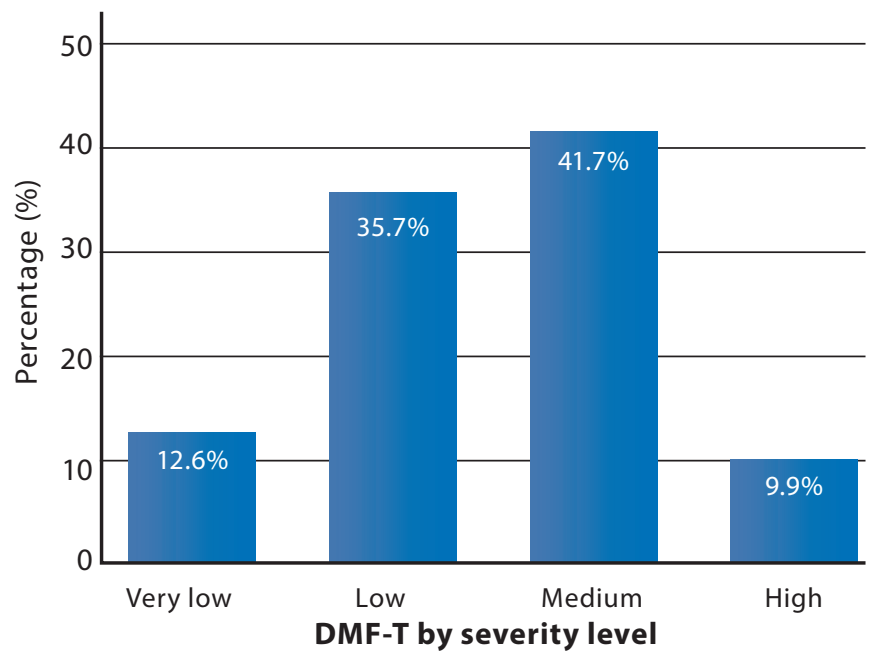


malocclusion), and extraoral appearance (normal or abnormal) (Table 3).

Data were recorded in a data collection sheet. Sociodemographic data and surveys were collected by interview, and the clinical data by oral examination.

The decision of each patient was respected, subjects were free to participate or withdraw from the study and continue receiving care in the same institution.
Likewise, participants were provided information about the study and the researcher. The data collected was kept confidential and the results presented globally. No subject was discriminated against for any reason, such as race, religion, etc. Permission was requested from the corresponding authorities for the execution of this study following the usual procedures of the Paraguayan legislation.

Table 1. Result of the calibration process of the two dentists in the performance of the oral examination in the clinic.

\begin{tabular}{lcc}
\hline Clinical evaluation & Kappa & $\boldsymbol{p}$-value \\
\hline Dentofacial abnormalities & 0.810 & $>0.001$ \\
Soft tissues & 0.846 & $>0.001$ \\
Dental status & 0.873 & $>0.001$ \\
\hline
\end{tabular}

Table 2. Table of sociodemographic variables.

\begin{tabular}{|c|c|c|}
\hline Variables & Definition & $p$-value \\
\hline Age & $\begin{array}{l}\text { Time that a person has lived at the time } \\
\text { of the study, measured in years }\end{array}$ & Subjects are grouped by decade \\
\hline Sex & $\begin{array}{l}\text { Category based on the reproductive } \\
\text { functions of the person }\end{array}$ & $\begin{array}{l}\text { Female } \\
\text { Male }\end{array}$ \\
\hline Current place of residence & Place where the person currently lives & $\begin{array}{l}\text { Asunción } \\
\text { Central Department } \\
\text { Interior of the country }\end{array}$ \\
\hline Educational level & $\begin{array}{l}\text { Highest level of complete studies. In the } \\
\text { case of incomplete studies, the previous } \\
\text { academic degree or qualification obtai- } \\
\text { ned is considered }\end{array}$ & $\begin{array}{l}\text { None } \\
\text { Primary education: } 6^{\text {th }} \text { grade completed } \\
\text { Secondary education: } 3^{\text {rd }} \text { year or } 9^{\text {th }} \text { grade } \\
\text { completed } \\
\text { Tertiary education: Technical or University } \\
\text { degree completed }\end{array}$ \\
\hline Occupation & Status of main job & $\begin{array}{l}\text { Self-employed } \\
\text { Financially dependent } \\
\text { Public or private company } \\
\text { Retired }\end{array}$ \\
\hline Income level & $\begin{array}{l}\text { Salary or wages earned monthly by the } \\
\text { person }\end{array}$ & $\begin{array}{l}\text { They are grouped into three levels: } \\
\text { Less than or equal to the minimum wage } \\
\text { ( }<1,964,507 \text { guaraníes) } \\
>1 \text { to } 2 \text { minimum wages }(1,964,507-3,929,014 \\
\text { guaraníes) } \\
\geq 3 \text { minimum wages ( } \geq 3,929,014 \text { guaraníes) }\end{array}$ \\
\hline Access to private health services & $\begin{array}{l}\text { If the person uses private medical or de- } \\
\text { ntal health services, either as part of an } \\
\text { insurance plan or on their own }\end{array}$ & Yes/No \\
\hline
\end{tabular}


Table 3. Table of clinical variables.

\begin{tabular}{|c|c|c|}
\hline Variables & Definition & $p$-value \\
\hline Self-perceived oral health status & $\begin{array}{l}\text { How the person assesses his/her general } \\
\text { oral health status }\end{array}$ & $\begin{array}{l}\text { Excellent } \\
\text { Very good } \\
\text { Good } \\
\text { Acceptable } \\
\text { Poor }\end{array}$ \\
\hline $\begin{array}{l}\text { Status of the temporo-mandibular } \\
\text { joint }\end{array}$ & $\begin{array}{l}\text { Evaluation of the TMJ assessing signs } \\
\text { and symptoms }\end{array}$ & $\begin{array}{l}\text { Symptoms: Yes/No } \\
\text { Signs: } \\
\text { Audible click } \\
\text { Tenderness } \\
\text { Reduced mobility (<30mm or two fingers) }\end{array}$ \\
\hline Molar ratio & $\begin{array}{l}\text { It determines the anteroposterior relati- } \\
\text { onship of the first permanent molars }\end{array}$ & $\begin{array}{l}\text { Normal } \\
\text { Semi-cusp } \\
\text { Full cusp }\end{array}$ \\
\hline Dentofacial abnormalities & $\begin{array}{l}\text { Severity of dental malocclusion and need } \\
\text { for treatment were observed according } \\
\text { to the Dental Aesthetic Index (DAl) }\end{array}$ & 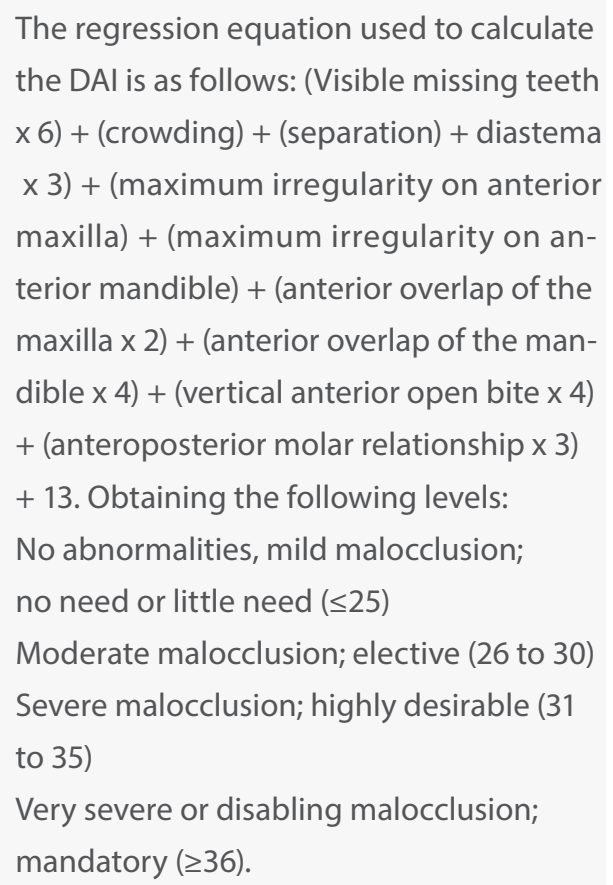 \\
\hline Extraoral exam & $\begin{array}{l}\text { Detection of lesions outside the oral ca- } \\
\text { vity, on the head and lips }\end{array}$ & $\begin{array}{l}\text { Normal extraoral appearance } \\
\text { Abnormal extraoral appearance: Ulcers, } \\
\text { inflammations, erosions, fissures (nose, } \\
\text { cheeks, chin) } \\
\text { Ulcers, inflammations, erosions, fissures } \\
\text { (corner of the lips) } \\
\text { Ulcers, inflammations, erosions, fissures } \\
\text { (vermilion border). Anomaly of the upper } \\
\text { or lower lips } \\
\text { Other swelling of the face and jaw } \\
\text { Others, not registered }\end{array}$ \\
\hline
\end{tabular}


Table 4. Caries experience by age group based on the DMF-T index.

\begin{tabular}{lllllll}
\hline \multirow{2}{*}{ Age groups } & \multicolumn{2}{c}{ Decayed } & \multicolumn{2}{c}{ Missing } & \multicolumn{2}{c}{ Filled } \\
& Mean & SD & Mean & SD & Mean & SD \\
\hline 18 to $29(n=137)$ & 2.93 & 3.38 & 2.59 & 3.87 & 2.67 & 2.76 \\
30 to $39(n=90)$ & 2.73 & 2.59 & 5.22 & 4.80 & 3.84 & 3.42 \\
40 to $49(n=40)$ & 1.93 & 2.11 & 7.33 & 6.040 & 4.65 & 4.17 \\
50 to $59(n=66)$ & 1.88 & 2.47 & 9.91 & 7.52 & 4.65 & 4.17 \\
\hline
\end{tabular}

Table 5. Severity level of the DMF-T Index according to sociodemographic variables.

\begin{tabular}{|c|c|c|c|c|c|c|c|c|c|c|c|}
\hline & & & & & veri & level & $f D M$ & & & & \\
\hline & & & Ver & low & & w & Mec & um & & & Total \\
\hline & & & $\mathrm{n}$ & $\%$ & $\mathbf{n}$ & $\%$ & $\mathbf{n}$ & $\%$ & $\mathbf{n}$ & $\%$ & $\mathbf{n}$ \\
\hline$(p=0.001)^{*}$ & Sex & Female & 31 & 12.0 & 80 & 31.0 & 115 & 44.6 & 32 & 12.4 & 258 \\
\hline & & Male & 11 & 14.7 & 39 & 52.0 & 24 & 32.0 & 1 & 1.3 & 75 \\
\hline$(p=0.168)$ & Place of residence & Asunción & 26 & 15.1 & 51 & 29.7 & 76 & 44.2 & 19 & 11.0 & 172 \\
\hline & & Central & 11 & 11.0 & 46 & 46.0 & 36 & 36.0 & 7 & 7.0 & 100 \\
\hline & & Interior & 5 & 8.2 & 22 & 36.1 & 27 & 44.3 & 7 & 11.5 & 61 \\
\hline$(p<0.001)^{*}$ & Educational level & None & 3 & 16.7 & 2 & 11.1 & 10 & 55.6 & 3 & 16.7 & 18 \\
\hline & & Primary & 0 & 0 & 26 & 32.1 & 40 & 49.4 & 15 & 18.5 & 81 \\
\hline & & Secondary & 25 & 16.7 & 54 & 36.0 & 61 & 40.7 & 10 & 6.7 & 150 \\
\hline & & Tertiary & 14 & 16.7 & 37 & 44.0 & 28 & 33.3 & 5 & 6.0 & 84 \\
\hline$(p=0.034)^{*}$ & Occupation & Employed & 16 & 15.4 & 36 & 34.6 & 46 & 44.2 & 6 & 5.8 & 104 \\
\hline & & Self-employed & 10 & 9.7 & 30 & 29.1 & 49 & 47.6 & 14 & 13.6 & 103 \\
\hline & & Dependent & 15 & 12.7 & 52 & 44.1 & 41 & 34.7 & 10 & 8.5 & 118 \\
\hline & & Retired & 1 & 12.5 & 1 & 12.5 & 3 & 37.5 & 3 & 37.5 & 8 \\
\hline$(p=0.001)^{*}$ & Place of origin & MSPyBS & & & & & & & & & \\
\hline & & Asunción & 2 & 3.3 & 20 & 32.8 & 32 & 52.5 & 7 & 11.5 & 61 \\
\hline & & MSPyBS & & & & & & & & & \\
\hline & & Pirayú & 1 & 2.2 & 18 & 39.1 & 22 & 47.8 & 5 & 10.9 & 46 \\
\hline & & Fundación & 1 & 3.6 & 6 & 21.4 & 17 & 60.7 & 4 & 14.3 & 28 \\
\hline & & FOUNA & 38 & 19.2 & 75 & 37.9 & 68 & 34.3 & 17 & 8.6 & 198 \\
\hline$(p=0.94)$ & Income level & None & 17 & 14.2 & 53 & 44.2 & 39 & 32.5 & 11 & 9.2 & 120 \\
\hline & & $\leq \mathrm{MW}$ & 16 & 10.5 & 43 & 28.3 & 74 & 48.7 & 19 & 12.5 & 152 \\
\hline & & 1 to $2 \mathrm{MW}$ & 5 & 12.2 & 17 & 41.5 & 16 & 39.0 & 3 & 7.3 & 41 \\
\hline & & $\geq 3 \mathrm{MW}$ & 4 & 20.0 & 6 & 30.0 & 10 & 50.0 & 0 & 0 & 20 \\
\hline$(p<0.001)^{*}$ & Age groups & 18 to 29 & 31 & 22.6 & 69 & 50.4 & 31 & 22.6 & 6 & 4.4 & 137 \\
\hline & & 30 to 39 & 7 & 7.8 & 30 & 33.3 & 45 & 50.0 & 8 & 8.9 & 90 \\
\hline & & 40 to 49 & 1 & 2.5 & 12 & 30.0 & 22 & 55.0 & 5 & 12.5 & 40 \\
\hline & & 50 to 59 & 3 & 4.5 & 8 & 12.1 & 41 & 62.1 & 14 & 21.2 & 66 \\
\hline
\end{tabular}

*: $p<0.05$. Pearson's Chi Square test or Fisher's exact test. MSPyBS: Ministry of Public Health and Social Welfare. FOUNA: School of Dentistry of Universidad Nacional de Asunción. MW: Minimum. Wage: 1,964,507. Guaranies: 358.74 Dollars (1 USD = 5,476.10 PYG as of March 31, 2017). 
Table 6. Severity level of the DMF-T Index according to clinical variables.

\begin{tabular}{|c|c|c|c|c|c|c|c|c|c|c|}
\hline & & \multicolumn{8}{|c|}{ Severity level of DMF-T } & \multirow{3}{*}{$\begin{array}{c}\text { Total } \\
\mathbf{n}\end{array}$} \\
\hline & & \multicolumn{2}{|c|}{ Very low } & \multicolumn{2}{|c|}{ Low } & \multicolumn{2}{|c|}{ Medium } & \multicolumn{2}{|c|}{ High } & \\
\hline & & $\mathbf{n}$ & $\%$ & $\mathbf{n}$ & $\%$ & $\mathbf{n}$ & $\%$ & $\mathbf{n}$ & $\%$ & \\
\hline \multirow[t]{2}{*}{ Access to private health services $(p=0.008)^{*}$} & No & 17 & 8.0 & 82 & 38.5 & 92 & 43.2 & 22 & 10.3 & 213 \\
\hline & Yes & 25 & 20.8 & 37 & 30.8 & 47 & 39.2 & 11 & 9.2 & 120 \\
\hline \multirow[t]{5}{*}{ Oral health self-assessment $(p=0.004)^{*}$} & Poor & 0 & 0 & 16 & 39.0 & 18 & 43.9 & 7 & 17.1 & 41 \\
\hline & Acceptable & 10 & 10.1 & 35 & 35.4 & 45 & 45.5 & 9 & 9.1 & 99 \\
\hline & Good & 14 & 13.2 & 41 & 38.7 & 41 & 38.7 & 10 & 9.4 & 106 \\
\hline & Very good & 15 & 27.8 & 21 & 38.9 & 16 & 29.6 & 2 & 3.7 & 54 \\
\hline & Excellent & 3 & 9.1 & 6 & 18.2 & 19 & 57.6 & 5 & 15.2 & 33 \\
\hline \multirow[t]{2}{*}{ Symptoms of TMJ $(p=0.320)$} & Yes & 9 & 12.5 & 27 & 37.5 & 33 & 45.8 & 3 & 4.2 & 72 \\
\hline & No & 33 & 12.6 & 92 & 35.2 & 106 & 40.6 & 30 & 11.5 & 261 \\
\hline \multirow[t]{3}{*}{ Molar ratio $(p=0.023)^{*}(n=274)$} & Normal & 18 & 11.3 & 63 & 39.6 & 70 & 44.0 & 8 & 5.0 & 159 \\
\hline & Semi-cusp & 5 & 11.1 & 23 & 51.3 & 15 & 33.3 & 2 & 4.4 & 45 \\
\hline & Full cusp & 19 & 27.5 & 29 & 42.0 & 20 & 29.0 & 1 & 1.4 & 69 \\
\hline \multirow[t]{4}{*}{ Dental Aesthetic Index $(p<0.001)^{*}$} & Mild & 19 & 20.9 & 50 & 54.9 & 20 & 22.0 & 2 & 2.2 & 91 \\
\hline & Moderate & 6 & 10.0 & 29 & 48.3 & 24 & 40.0 & 1 & 1.7 & 60 \\
\hline & Severe & 6 & 16.2 & 16 & 43.2 & 14 & 37.8 & 1 & 2.7 & 37 \\
\hline & Very severe & 10 & 12.0 & 19 & 22.9 & 47 & 56.6 & 7 & 8.4 & 83 \\
\hline \multirow[t]{2}{*}{ Click of the TMJ $(p=0.821)$} & Yes & 18 & 12.1 & 52 & 34.9 & 66 & 44.3 & 13 & 8.7 & 149 \\
\hline & No & 24 & 13.0 & 67 & 36.4 & 73 & 39.7 & 20 & 10.9 & 184 \\
\hline \multirow[t]{2}{*}{ Pain on palpation of the TMJ $(p=0.060)$} & Yes & 5 & 21.7 & 12 & 52.2 & 6 & 26.1 & 0 & 0 & 23 \\
\hline & No & 37 & 11.9 & 107 & 34.5 & 133 & 42.9 & 33 & 10.6 & 310 \\
\hline \multirow[t]{2}{*}{ Lesions in the oral mucosa $(p=0.523)$} & Yes & 4 & 10.3 & 13 & 33.3 & 20 & 51.3 & 2 & 5.1 & 39 \\
\hline & No & 38 & 12.9 & 106 & 36.1 & 119 & 40.5 & 31 & 10.5 & 294 \\
\hline \multirow[t]{2}{*}{ Extraoral appearance $(p=0.821)$} & Normal & 2 & 8.3 & 10 & 41.7 & 9 & 37.5 & 3 & 12.5 & 24 \\
\hline & Abnormal & 40 & 12.9 & 109 & 35.3 & 130 & 42.1 & 30 & 9.7 & 309 \\
\hline
\end{tabular}

Descriptive and inferential statistics were applied. The results were presented in tables and graphs, absolute frequency and percentage were used for categorical variables, and measures of central tendency and dispersion for quantitative variables. The statistical tests Chi square and Fisher's exact test were used with a confidence level of 95\%. The IBM SPSS (Statistical Package for Social Science) Version 22.0 program was used.

\section{RESULTS.}

A total of 333 subjects participated in the study, mean age was 35 ( $S D=13$ years), $77.2 \%$ were females, 51.7\% lived in Asunción, 25.2\% had tertiary education, $35.4 \%$ were financially dependent, $71.0 \%$ earned an income lower than the minimum wage, and $64.0 \%$ did not have access to private health services.

Regarding the severity level of the DMF-T Index, $35.7 \%$ of the adults had a low level, and $41.7 \%$ had a medium level (Figure 2). Decayed teeth accounted for $22.3 \%$, missing $46.6 \%$, and filled $31.2 \%$. The overall DMF-T was 11.43 (SD=6.7); 79.6\% of participants were partially edentulous, $20.1 \%$ had no missing teeth, and $0.3 \%$ were totally edentulous.

It was observed that the presence of caries decreased as the age group increased, while missing and filled teeth increased as the age group increased (Table 4). It was observed that the severity level of the caries history was not distributed homogeneously by age groups, sex, educational level, occupation, or place 
of origin (Table 5). Among the clinical variables, the level of severity of the caries history was statistically significant for the following variables: access to health services, self-perception of oral health status, molar ratio, and dental aesthetics index (Table 6).

\section{DISCUSSION.}

From the results obtained in this research, it can be observed that the DMF-T continues to remain at a medium level with a value of 11.43. This figure agrees with data reported in the national oral health surveys in previous years. This result can be compared with those obtained in other countries and other age groups in Paraguay. The DMF-T index of this study was equal to those of adults from Medellín, Colombia (11.0), ${ }^{14}$ slightly lower than the 13.2 reported in patients aged 12 to 65 who attended dental clinics in the Department of Itapúa, Paraguay, ${ }^{15}$ but higher than the results obtained in indigenous Paraguayans aged 20 to 40 years in $1984 ;^{3}$ lower, with a little less than half, than those obtained in adults aged 20 to 64 from Piracacicaba in São Paulo, Brazill, ${ }^{16}$ Chilean adults aged 35 to 44 years with $14.89,{ }^{17}$ and pregnant Palestinian women with $15.5 .{ }^{18}$ A statistically significant difference by age group was found in this research, similar to data reported in a study conducted in adults aged $18-75$ years in Kosovo, ${ }^{19}$ and in Colombian adults aged 25 to 65 years. ${ }^{14}$ Likewise, missing teeth tended to increase with age. This figure agrees with the result obtained in the study carried out in Paraguayan and Colombian adults. ${ }^{14,15}$

However, in the present study, this component was lower than the $84.3 \%$ reported in Brazilian adults. ${ }^{16}$ On average, Paraguayan adults presented a problem in almost half of their dentition, either because their teeth were decayed, filled, or missing. This reveals the poor access to health services in the country, as documented by Caballero-García et al., ${ }^{15}$ who reported that $77 \%$ did not have access to private health services, a figure slightly higher than the one reported in this study. Likewise, the increase in missing teeth highlights the need for the promotion of oral health, as reported by several national studies conducted in other population groups., ${ }^{7,20-22}$

A statistically significant difference was found in the DMF-T Index according to educational level, being higher at lower academic level, similar to the finding reported in Hungarian police students. ${ }^{23}$ On the other hand, a significant difference was found by sex, as severe caries lesions were more prevalent in women. This could be because women's oral health declines more rapidly with age, which could be due to fertility, that is, the complex and synergistic changes associated with female sex hormones, pregnancy, and female reproductive history. ${ }^{24}$

It was found that the level of severity of dental caries was associated with sociodemographic and clinical variables. This could be due to the fact that patients who have a very severe dental aesthetics index also have missing teeth or inadequate positions of the teeth, which contributes to food accumulation on the teeth, and consequently a greater amount of caries. In addition, it should be considered that the DMF-T index corresponds to the history of caries, and it is a powerful indicator of future damage.

Patients who use the Foundation live in the "Ricardo Brugada" neighborhood of the city of Asunción. This is a neighborhood for people of low socioeconomic level, on the extreme poverty line, and even their basic needs are unsatisfied. Among them, access to oral health services is difficult, which could be reflected on the high level of dental caries observed. However, it should also be considered that patients who selfperceived their oral health as excellent had a high level of severity regarding caries. This could possibly correspond only to this group of patients, because as they have other unmet basic needs, they stop considering oral health as a problem, thus reducing its importance, which is reflected in the undervaluation of their oral health status.

In a study carried out on potential health demands based on the demographic changes in Paraguay in 2017, it was found that $74.1 \%$ of the population did not have access to health services, among them 65.7\% were from rural areas, and 87.4\% from urban ones. ${ }^{25}$ This result agrees with the one reported in this study, where $64 \%$ indicated not having access to private health services. It should be considered that the Paraguayan health system is made up of three paradigms, which are hospitalization, decentralization, and prevention; in turn, it consists of three systems: private, insurance for employed workers, and public 
health for the rest of the citizens. ${ }^{26}$

On the other hand, the sample only covers two regions and does not include indigenous populations, which is why it would not be advisable to extrapolate the results to the entire population. However, the sample could be representative in terms of social strata, since it includes a very poor area such as the Ricardo Brugada neighborhood known as "La Chacarita". The patients who came to FOUNA (School of Dentistry of Universidad Nacional de Asunción) are from different parts of the country. They go there because it is more affordable and has a good reputation. Such is the case with the patients coming from the Pirayú region, who live in the interior of the country, where there are very few private dental clinics. There is stark inequality in access to health services, and although the evidence is still very scarce, it has been reported that care provision for Paraguayan children and adults increases according to income level. ${ }^{27}$

It should be noted that these results can be a reference for the oral health status of the Paraguayan adult population at the national level, since there have not been other reports on the adult population since 1974. Another strength of this study is that many associations have been found between variables that had never been studied before. However, the influence of the determinants of the oral health status of the population should be carefully analyzed, which goes beyond the access to dental care.

\section{CONCLUSION.}

It is concluded that the general level of severity of global caries was medium and was associated with sociodemographic and clinical variables. It is recommended to reinforce measures of promotion and prevention in oral health.
Conflict of interests: The authors report no current or potential conflicts of interest. This article is part of the thesis of Díaz-Reissner $C$ to obtain a PhD in Methodology of Biomedical and Public Health Research at the Universitat Autònoma de Barcelona, Spain.

Ethics approval: Informed consent was obtained from all patients who participated in the study.

Funding: Selfunding.

Authors' contributions: Contributed to conception and design, data collection, analysis and interpretation, and drafted the manuscript: Díaz-Reissner C. Contributed to design and critically revised the manuscript: RoldánMerino J and Casas García I. All authors gave final approval and agreed to be accountable for all aspects of work.

Acknowledgements: The authors wish to acknowledge the contribution of the data collection to Milner Morel, DDS and Leticia Cataldi, DDS. 


\section{REFERENCES.}

1. Contreras Rengifo A. La promoción de la salud general y la salud oral: una estrategia conjunta. Rev Clínica Periodoncia, Implantol y Rehabil Oral. 2016;9(2):193-202.

2. Federal Dental International World Dental Federation. El desafío de las enfermedades bucodentales. Una llamada a la acción global. Atlas de Salud Bucodental. 2da ed. Brighton: FDI; 2015.

3. Kieser JA, Preston CB. Oral health status of the Lengua Indians of Paraguay. Community Dent Oral Epidemiol. diciembre de 1984;12(6):406-7.

4. Naranjo CD. Representation de la caries en el mundo a través de mapas. Univ Odontológica. 2012;31(66):41-50.

5. Ministerio de Salud Pública y Bienestar Social, Organizacion Panamericana de la Salud. Encuesta Nacional sobre Salud Oral Paraguay 2008. OPS. Whasington, DC.: Dirección de Salud Bucodental; 2008.

6. Ministerio de Salud Pública y Bienestar Social. Encuesta nacional de salud bucal del Paraguay, ENSABUD PY 2017: del diagnóstico al diseño y la ejecucción de políticas públicas de salud budocental. Asunción: OPS/OMS; 2018.

7. Almirón Pereira PA, Denis SE, Morales A, Britez E, Macchi AA, Maidana JA, et al. Condiciones de salud oral en ancianos del club geriátrico "Abue-Club" en Paraguay. Memorias del Inst Investig en Ciencias la Salud. 2016;14(1):32-9.

8. Díaz-Reissner CV, Pérez-Bejarano NM, Ferreira-Gaona MI, Sanabria-Vázquez DA, Torres-Amarilla CD, Araujo A, Fernández B, Fleitas D, Real C, Godoy J, Paéz E. Autopercepción de la calidad de vida relacionada con salud oral en adultos mayores residentes en albergues nacionales del área metropolitana, Paraguay. Rev Odontológica Latinoam Latinoam. 2015;7(1):23-31.

9. Mancuello Alum JN, Cabral de Bejarano MS. Sistema de Salud de Paraguay. 2011;1(1):13-25.

10. Pan American Health Organization. Health in the Americas, 2017. Edition. Summary: Regional Outlook and Country Profiles. 2017. Ed. Whasington D.C.PAHO; 2017.

11. Paiva SM,Abanto J, MattaAC,Antonio R, Masoli C, Echevarr SA, Schneider A. Relatorios de la mesa de representantes de sociedades de Odontopediatría de los países Latinoamericanos Relatório da mesa dos representantes das sociedades de Odontopediatria dos países Latinoamericanos São Paulo 2014 Epidemiología de la caries dental. Rev Odontopediatria Latinoam. 2014;4(2014):13-8.

12. Organización Mundial de la Salud. Encuestas de salud bucodental : métodos básicos. 1997.

13. de la Fuente-Hernández J, Sumano-Moreno O, SifuentesValenzuela M, Zelocuatecatl-Aguilar A. Impacto de la salud bucal en la calidad de vida de adultos mayores demandantes de atención dental. Univ Odontológica. 2010;29(63):83-92.

14. Ramírez-Puerta BS, Agudelo-Suárez AA, Morales-Flórez JL, Sarrazola-Moncada ÁM. Dientes presentes en población de 25, 35, 45, 55 y 65 años, Antioquia (Colombia) 2011. CES Odontol. 2012;25(2):12-23.

15. Caballero-García CR, Espínola-Verdún PA, Domínguez-
González DD, Martínez-Benítez GG, Figueredo-Palacios S, Fernández-Cáceres AM, et al. Salud bucodental y utilización de servicios odontológicos. Memorias del Inst Investig en Ciencias la Salud. 11 de marzo de 2018;15(3):57-63.

16. Manoelito Ferreira S-J, Anne Caroline Correia de S, Marília Jesus B, Maria da Luz Rosário de S. Condição de saúde bucal e motivos para extração dentária entre uma população de adultos (20-64 anos) / Oral health condition and reasons for tooth extraction among an adult population (20-64 years old). Cien Saude Colet. 2017;(8):2693.

17. Quinteros ME, Cáceres DD, Soto A, Mariño RJ, Giacaman RA. Caries experience and use of dental services in rural and urban adults and older adults from central Chile. Int Dent J. 2014;64(5):260-8.

18. Kateeb E, Momany E. Dental caries experience and associated risk indicators among Palestinian pregnant women in the Jerusalem area: A cross-sectional study. BMC Oral Health. 2018;18(1):1-9.

19. Kamberi B, Koçani F, Begzati A, Kelmendi J, Ilijazi D, Berisha $\mathrm{N}$, et al. Prevalence of Dental Caries in Kosovar Adult Population. Int J Dent. 2016;6 pages.

20. Sanabria-Vázquez DA, Gaona F, Inés M, Pérez-Bejarano NM, Díaz-Reissner CV, Torres-Amarilla CD, et al. Caries dental en menores en situación de pobreza, asistidos por una fundación en Paraguay. Rev Estomatológica Hered. abril de 2016;26(2):707.

21. Pérez-Bejarano NM, Alarcón-Gónzalez VS, Ferreira-Gaona MI, Díaz-Reissner CV. Estado de Salud Oral en Discapacitados Residentes en la Fundación Pequeño Cottolengo Don Orione, Paraguay. Int J Odontoestomatol. 2016;10(1):69-74.

22. Pérez-Bejarano NM, Ferreira-Gaona MI, Díaz-Reissner CV, Sanabria-Vazquez DA, Torres-Amarilla CD, Acosta-Parra EB, et al. Oral health in adolescents with disabilities from "Centro de Educación Especial San Miguel”, Guarambaré, Paraguay. Rev Fac Odontol Univ Antioq. 2017;29(1):51-64.

23. Faragó I, Nagy G, Márton S, Túry F, Szabó E, Hopcraft M, et al. Dental caries experience in a Hungarian police student population. Caries Res. 2012;46(2):95-101.

24. Lukacs JR. Sex differences in dental caries experience: Clinical evidence, complex etiology. Clin Oral Investig. 2011;15(5):649-56.

25. Zavattiero C,Fantin MA,Zavattiero Tornatore G. Estimation of potential health demands from changes in population dynamics in Paraguay. Población y Desarro. 2017;23(45):2-15.

26. Caballero EG, Rodríguez JC, Peralta N. Espacios de decisión en la descentralización de salud del Paraguay. Memorias del Inst Investig en Ciencias la Salud. 30 de marzo de 2016;14(3).

27. Capurro D, Robledo L. Tendencia de la inequidad socioeconómica en la utilización de servicios de salud en el Paraguay. Asunción; 2016. 